\title{
HISTO-BLOOD GROUP LEWIS GENOTYPING FROM HUMAN HAIRS AND BLOOD
}

\author{
Shin Yazawa, ${ }^{1, *}$ Hitoshi OH-Kawara, ${ }^{2}$ Tamiko Nakajima, ${ }^{1}$ \\ Osamu Hosomi, ${ }^{1}$ Suguru AKamatsu, ${ }^{3}$ and Koichiro KISHI ${ }^{1}$ \\ ${ }^{i}$ Department of Legal Medicine, Gunma University School of Medicine, \\ 3-39-22 Showa-machi, Maebashi 371, Japan \\ ${ }^{2}$ Scientific Crime Laboratory, Gunma Prefecture Police Headquarters, \\ 523 Soja-machi, Maebashi 371, Japan \\ ${ }^{3}$ Diagnostic Division, Otsuka Pharmaceutical Co. Ltd., \\ 224-18 Kawauchi-machi, Tokushima 771-01, Japan
}

\begin{abstract}
Summary The expression of histo-blood group Lewis antigens is determined by the Lewis-type $\alpha 1 \rightarrow 3 / 4$ fucosyltransferase (Le enzyme) encoded by Fuc-TIII gene ( $L e$ gene). The genotyping of $L e$ genes by the PCR-RFLP methods established recently and partly modified in this study was found to be useful not only for determining the genuine Lewis blood types of samples such as human hairs and blood stains but also for distinguishing non-genuine Lewis-negative phenotypes frequently observed in pregnant women from genuine ones. The availability of the present PCR-RFLP methods for the paternity tests was also discussed.

Key Words Lewis blood group genotyping, PCR-RFLP, non-genuine Lewis-negative phenotypes
\end{abstract}

\section{INTRODUCTION}

The histo-blood group Lewis antigens comprise $\mathrm{Le}^{\mathrm{a}}$ and $\mathrm{Le}^{\mathrm{b}}$ antigens and their antigenic determinants have been determined to be Gal $\beta 1 \rightarrow 3$ [Fuc $\alpha 1 \rightarrow 4$ ]GlcNAc $\beta$ and Fuc $\alpha 1 \rightarrow 2 \operatorname{Gal} \beta 1 \rightarrow 3[\operatorname{Fuc} \alpha 1 \rightarrow 4]$ GlcNAc $\beta$, respectively (Watkins, $1980)$. The Lewis blood group phenotypes have been determined by serological examinations of red blood cells and saliva through hemagglutination tests and hemagglutination inhibition tests using anti-Le $\mathrm{C}^{\mathrm{a}}$ and anti-Le $\mathrm{e}^{\mathrm{b}}$ antibodies. They are grouped as $\operatorname{Le}(a+b-)$ and $\operatorname{Le}(a-b+)$ (Lewis positive) and $\operatorname{Le}(a-b-)$ (Lewis negative) individuals. To date a large number of anti-Lewis monoclonal antibodies have been raised and some of them have been commercially available as is usually the case with monoclonal antibodies against most blood group antigens (Oriol et al., 1990; Good et al., 1992). However, the Lewis blood group pheno-

Received September 11, 1995; Revised version accepted November 14, 1995.

* To whom correspondence should be addressed. 
types have been typed in error due to the specificities of anti-Le ${ }^{a}$ and anti-Le ${ }^{b}$ antibodies (Yazawa et al., 1993, 1995). The Lewis blood group phenotypes of red blood cells have been reported to change in pregnancy (Hammer et al., 1981), alcoholic cirrhosis and pancreatitis (Stigendal et al., 1984), hydatid cysts (Makni et al., 1987) and cancers (Ernst et al., 1984; Limas, 1986; Hirano et al., 1987; Yazawa et al., 1988; Ørntoft et al., 1991). The Lewis blood group antigens could also be found in Lewis-negative individuals (Limas, 1986; Ørntoft et al., 1991). In these cases, the genuine Lewis blood types could not be always correctly determined from the serological tests.

Recently, molecular analyses of blood group related genes have been developed (Lutz and Dzik, 1992; Schachter, 1994), and our previous study on the genomic structures of Le genes from Lewis-positive and Lewis-negative individuals demonstrated that three missence mutations were present in le genes (Nishihara $e t$ al., 1994). The le alleles were divided into two types, lel having the T59 to $\mathrm{G}$ and $\mathrm{G} 508$ to $A$ mutations, and le2, having the T59 to $\mathrm{G}$ and T1067 to A mutations (Nishihara et al., 1994) (Fig. 1). In addition, the first mutation (T59 to G) was found to occur unexceptionally in le genes and to become a genetic marker to distinguish between Lewis-positive and Lewis-negative individuals (Nishihara et al., 1993, 1994; Yazawa et al., 1995). We have also developed PCR-RFLP methods to detect the aforementioned three missence mutations in le genes (Nishi-

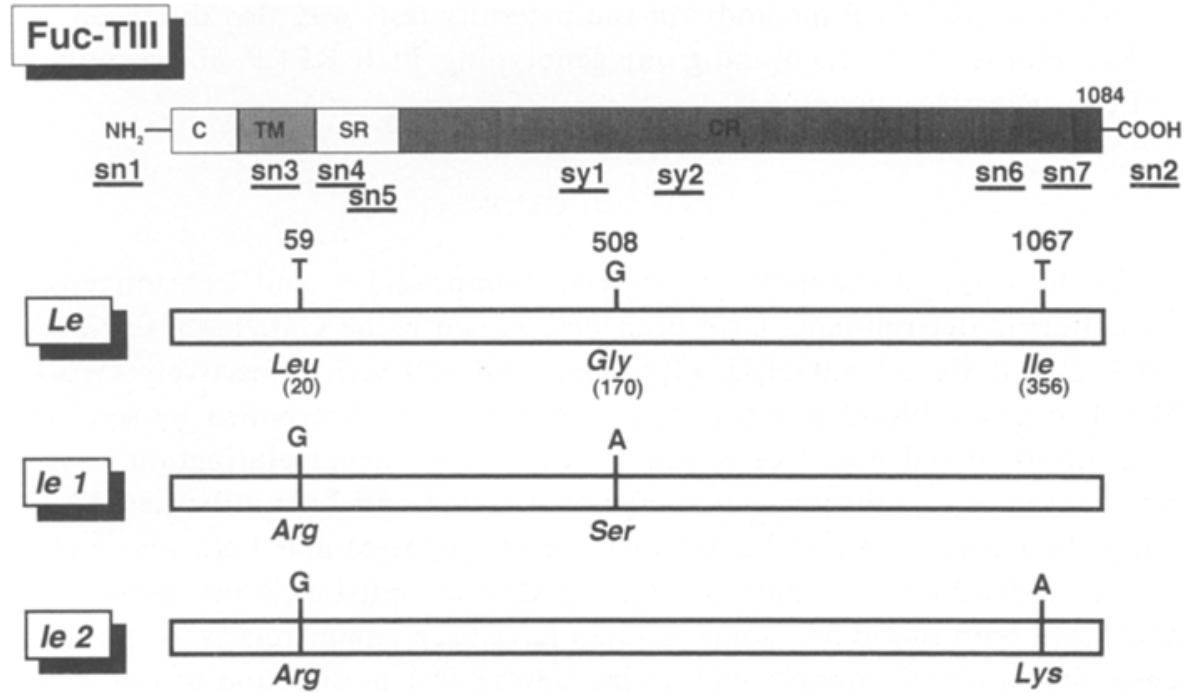

Fig. 1. Schematic comparison of Fuc-TIII nucleotide sequences from Le and le genes and the location of PCR primers. C, TM, SR and CR indicate cytoplasmic tail, transmembrane domain, stem region and catalytic region, respectively. sn1, sn2, sn $3, \operatorname{sn} 4, \operatorname{sn} 5, \operatorname{sn} 6, \operatorname{sn} 7$, syl and sy 2 indicate location of PCR primers used in this study. 
hara et al., 1994). The incompatibility of Lewis phenotypes was observed in patients with cancers (Yazawa et al., 1988), and the presence of Le enzyme activity in saliva from cancer patients seemed to be consistent with that of Le gene (Yazawa et al, 1988, 1995). In order to determine the genuine Lewis blood types of such cancer patients, we analyzed their Lewis genotypes, and found that the patients whose salivas had Le enzyme activity possessed at least one Le gene even though the Lewis phenotypes of their erythrocytes and salivas were Lewis-negative (Yazawa et al., 1995).

In this study, we determined the Lewis genotypes of samples obtained from human hairs and blood stains with the aid of PCR-RFLP methods previously developed and partly modified in this study. We also analyzed, for the first time, the Lewis genotypes of pregnant women with Lewis-negative erythrocytes and of the individuals in the paternity tests to evaluate the usefulness of the present PCR-RFLP methods for the determination of Lewis genotypes.

\section{MATERIALS AND METHODS}

Materials. GDP-L- $\left[{ }^{3} \mathrm{H}\right]$ fucose $(85.1 \mathrm{GBq} / \mathrm{mmol})$ and Aquasol-2 were purchased from Du Pont (Boston, MA, U.S.A.). GDP-fucose was from Sigma (St. Louis, MO, U.S.A.). Sep-Pak plus $\mathrm{C}_{18}$ reverse-phase cartridges were from Waters (Milford, CT, U.S.A.). Anti-Le ${ }^{\mathrm{a}}$ (2DG8) and anti-Le ${ }^{\mathrm{b}}$ (TT42) monoclonal antibodies were obtained as described previously (Yazawa et al., 1993). Anti-Lea (lot AU2-070) and anti-Le ${ }^{\mathrm{b}}$ (lot LAR-1018) monoclonal antibodies for hemagglutination test and hemagglutination inhibition tests were obtained from Chembiomed (Edmonton, Alberta, Canada). MspI, PvuII, HindIII enzymes, recombinant Taq DNA polymerase and deoxyribonucleoside triphosphates mixture were purchased from Takara (Ohtsu, Japan). Expand Long Template PCR System was from Boehringer Mannheim (Tokyo, Japan). 2'-O-Methyllacto- $N$-biose I $\beta$ Bn was prepared as described previously (Yazawa et al., 1990a). Freshly plucked hairs from head were obtained from 12 healthy volunteers with different Lewis blood group phenotypes. Blood and salivas were also obtained from healthy individuals and pregnant women.

Genomic DNA. Genomic DNA was prepared from either peripheral blood leukocytes or human hairs and blood specimens by Proteinase K-SDS method (Sabrock et al., 1992).

Determination of Lewis blood phenotypes and levels of Lewis antigens. Lewis blood phenotypes of samples were determined by a standard test of erythrocytes and saliva, under standard serological techniques (American Association of Blood Banks, 1981). Serum levels of $\mathrm{Le}^{\mathrm{a}}$ and $\mathrm{Le}^{\mathrm{b}}$ antigens were measured by enzyme-linked immunosorbent assay using anti-Le ${ }^{a}$ (2DG8) and anti-Le ${ }^{b}$ (TT42) monoclonal antibodies and expressed in an arbitrary unit $(\mathrm{U} / \mathrm{ml})$ by comparison with standard $\mathrm{Le}^{\mathrm{a}}$ and $\mathrm{Le}^{\mathrm{b}}$ antigens prepared from human meconium (Yazawa et 
al., 1990b) (details of the method will be published elsewhere).

Assay of Le enzyme activity. The standard reaction mixture for Le enzyme $(\alpha 1 \rightarrow 3 / 1 \rightarrow 4$ fucosyltransferase) assay contained the following components in a final volume of $100 \mu \mathrm{l}: 25 \mu \mathrm{M}$ GDP- $\left[{ }^{3} \mathrm{H}\right]$ fucose, $50 \mathrm{~mm}$ Tris- $\mathrm{HCl}(\mathrm{pH} 7.2), 10 \mathrm{~mm}$ $\mathrm{NaN}_{3}, 10 \mathrm{mM} \mathrm{MnCl}_{2}, 5 \mathrm{mM}$ ATP, $10 \mu \mathrm{l}$ saliva and $50 \mathrm{~mm} \mathrm{2}$ - $O$-methyllacto- $N$ biose $\mathrm{I} \beta \mathrm{Bn}$. After incubation at $37^{\circ} \mathrm{C}$ for $5 \mathrm{hr}$, an equal volume of absolute ethanol was added and the mixture was centrifuged. The enzyme activity of the supernatant was measured by the method described previously using Sep-Pak plus $\mathrm{C}_{18}$ (Yazawa et al., 1992).

PCR-RFLP methods. The PCR primers to obtain the full-length open reading frame of the Fuc-TIII gene (Nishihara et al., 1994) and to detect the mutations are listed in Table 1. Genomic DNA ( $500 \mathrm{ng}$ ) was amplified in $50 \mu 1$ of solution containing sn 1 and sn2 primers (Nishihara et al., 1994) (1 $\mu \mathrm{M}), 200 \mu \mathrm{M}$ each dNTP, $50 \mathrm{~mm}$ Tris- $\mathrm{HCl}(\mathrm{pH} 9.2), 14 \mathrm{mM}\left(\mathrm{NH}_{4}\right)_{2} \mathrm{SO}_{4}, 2.25 \mathrm{mM} \mathrm{MgCl}_{2}, 2 \%$ (v/v) DMSO, 0.1\% (v/v) Tween 20 and 2.6 units Taq (Expand Long Template PCR System containing thermostable Taq and Pwo DNA polymerases). Thirty cycles $\left(2 \mathrm{~min}\right.$ at $94^{\circ} \mathrm{C}, 2 \mathrm{~min}$ at $60^{\circ} \mathrm{C}, 2 \mathrm{~min}$ at $72^{\circ} \mathrm{C}$ ) were run to obtain the fulllength open reading frame of the Fuc-TIII gene. The product of the first PCR amplifications was subsequently used for the following PCRs as a template to detect the three missence mutations. To detect the T59G mutation, the first PCR product was then amplified in $50 \mu \mathrm{l}$ of solution containing sn 3 and sn 4 primers (1 $\mu \mathrm{M}$ ), $200 \mu \mathrm{M}$ each dNTP, $10 \mathrm{~mm}$ Tris- $\mathrm{HCl}$ (pH 8.8), $50 \mathrm{~mm} \mathrm{KCl}, 2.5 \mathrm{mM} \mathrm{MgCl}, 0.1$ $\mathrm{mg} / \mathrm{ml}$ gelatin and 2.5 units of Taq polymerase. The first cycle $\left(3 \mathrm{~min}\right.$ at $94^{\circ} \mathrm{C}, 2$ $\min$ at $62^{\circ} \mathrm{C}$, and $3 \mathrm{~min}$ at $72^{\circ} \mathrm{C}$ ) was run, then followed by 39 cycles $\left(1 \mathrm{~min}\right.$ at $94^{\circ} \mathrm{C}$, $1.5 \mathrm{~min}$ at $62^{\circ} \mathrm{C}$, and $1.5 \mathrm{~min}$ at $72^{\circ} \mathrm{C}$ ). To detect the G508A mutation, the first PCR product was amplified in $50 \mu 1$ of the same solution except syl and sy 2 primers ( 1 $\mu \mathrm{M})$. One cycle $\left(3 \mathrm{~min}\right.$ at $\left.93^{\circ} \mathrm{C}\right)$ and 30 cycles $\left(1 \mathrm{~min}\right.$ at $93^{\circ} \mathrm{C}, 1.5 \mathrm{~min}$ at $55^{\circ} \mathrm{C}, 1.5$ $\min$ at $\left.72^{\circ} \mathrm{C}\right)$ and one cycle $\left(5 \mathrm{~min}\right.$ at $\left.72^{\circ} \mathrm{C}\right)$ were run. To detect the T1067A

Table 1. PCR primers for the amplification of Fuc-TIII genes.

\begin{tabular}{|c|c|c|c|}
\hline $\begin{array}{l}\text { Primer } \\
\text { set }^{1}\end{array}$ & $\begin{array}{l}\text { Annealing } \\
\text { temperature }\left({ }^{\circ} \mathrm{C}\right)\end{array}$ & $\begin{array}{l}\text { Product } \\
\text { size (bp) }\end{array}$ & Sequence \\
\hline $\operatorname{sn} 1$ & 60 & 1,615 & $\begin{array}{l}\text { 5'-CTCGAATTCTAAGCAGGAGATTGTCATCAC- } \\
\text { TGACC-3' }\end{array}$ \\
\hline $\operatorname{sn} 2$ & & & $\begin{array}{l}\text { 5'-CTCAAGCTTCGTGCCGTGATGATCTCTCTG- } \\
\text { CAC-3' }\end{array}$ \\
\hline $\operatorname{sn} 3$ & 62 & 93 & 5'-CCATGGCGCCGCTGTCTGGCCGCCC-3' \\
\hline $\operatorname{sn} 4$ & & & 5'-AGTGGCATCGTCTCGGGACACACG-3' \\
\hline sy1 & 55 & 202 & $5^{\prime}$-GAAGCCCTGGACAGATACTTCA-3' \\
\hline sy2 & & & 5'-GCAGGCTCTGGTAGTAGCGCA-3' \\
\hline $\operatorname{sn} 6$ & 60 & 109 & $5^{\prime}$-CGCTCCTTCAGCTGGGCACTGGA-3' \\
\hline $\operatorname{sn} 7$ & & & $5^{\prime}$-CGGCCTCTCAGGTGAACCAAGAAGCT-3' \\
\hline
\end{tabular}

${ }^{1}$ Primers except syl and sy2 were shown in J Biol Chem 269: 29271-29278, 1994. 
mutation, the first PCR product was amplified in $50 \mu 1$ of the same solution except sn6 and $\operatorname{sn} 7(1 \mu \mathrm{M})$. Thirty cycles $\left(1 \mathrm{~min}\right.$ at $94^{\circ} \mathrm{C}, 2 \mathrm{~min}$ at $60^{\circ} \mathrm{C}, 2 \mathrm{~min}$ at $\left.72^{\circ} \mathrm{C}\right)$ were run. The second PCR products for detection of T59G, G508A and T1067A mutations were digested by $M s p \mathrm{I}, P v u I I$ and HindIII, respectively, and then analyzed by $1.5 \%$ Synergel (BioCraft, Tokyo, Japan) $+0.7 \%$ agarose gel electrophoresis.

\section{RESULTS AND DISCUSSION}

The Fuc-TIII gene is a member of the $\alpha 1 \rightarrow 3$ fucosyltransferase gene family and determines the expression of Lewis antigens (Kukowska-Latallo et al., 1990). The genomic structure analyses of Fuc-TIII genes from Le-negative individuals in our previous studies (Nishihara et al., 1993, 1994) demonstrated that the three missense mutations, i.e., the T59G, the G508A and T1067A were present in le genes. To detect these three mutations found in le genes, PCR-RFLP methods were also developed (Nishihara et al., 1994) and the usefulness of the methods was demonstrated when the genuine Lewis blood types were determined in cancer patients whose salivas contained Le enzyme even though they were phenotyped as Lewis-negative from their erythrocytes (Yazawa et al., 1995).

While the methods for Lewis genotyping previously reported were simple, it happened occasionally that the PCR amplification using sn5 and sn2 primers (Nishihara et al., 1994; Yazawa et al., 1995) was incomplete to obtain the 1.4-kbp fragment of Fuc-TIII which was necessary for the analyses of both G508A and T1067A mutations (Nishihara et al., 1994; Yazawa et al., 1995). Therefore, we modified the previously reported methods as follows. In order to obtain the adequate amount of the template for second PCRs encompassing positions 59, 508 and 1067, we used the expanded long template PCR system with sn1 and sn2 primers. Using the first PCR products as the template, the 93-bp PCR fragment was amplified with sn3 and sn 4 primers as described in "MATERIALS AND METHODS." As demonstrated previously (Nishihara et al., 1994), both the artificial change at position 57 of Fuc-TIII sequence from A to C with sn 3 primer and T59G mutation created an MspI site, CCGG. The 93-bp PCR fragment was then cleaved into two fragments, 68 and $25 \mathrm{bp}$ (Fig. 2, upper panel). For the detection of the G508A mutation, we synthesized a new primer set, syl and sy2 (Table 1). The syl primer had the sense nucleotide sequence corresponding to the sequence from position 439 to 460 of the Fuc-TIII gene. On the contrary, the sy 2 primer had the antisense nucleotide sequence corresponding to the sequence from position 592 to 602 . The change at position 508 created a $P v u I I$ site, CAGCTG and the 202-bp fragment was then cleaved into two fragments, 131 and 71 bp (Fig. 2, middle panel). The sn 7 primer had the antisense nucleotide sequence to the sequence from positions 1067 to 1093 of the Fuc-TIII gene with the mismatched position 1071 and 1072. The amplified 109-bp PCR fragment of the template possessing the T1067A mutation 


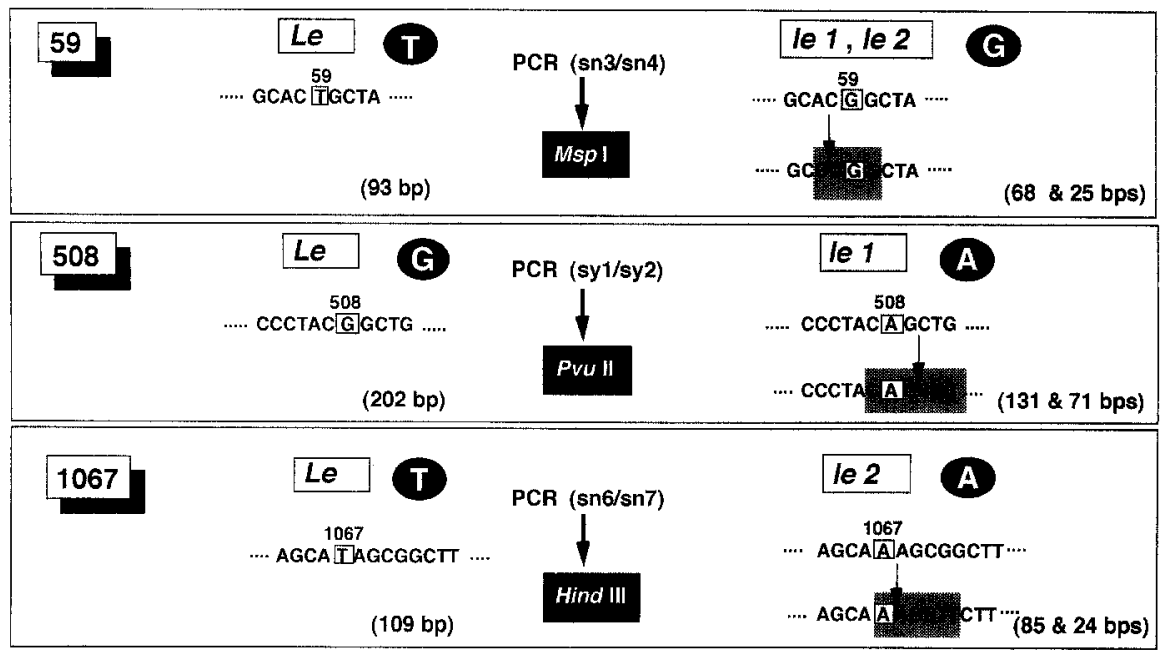

Fig. 2. Schematic illustration of PCR-RFLP methods detecting three missence mutations found in $l e$ genes. Shaded area shows new sites created for the action of the restriction enzymes.

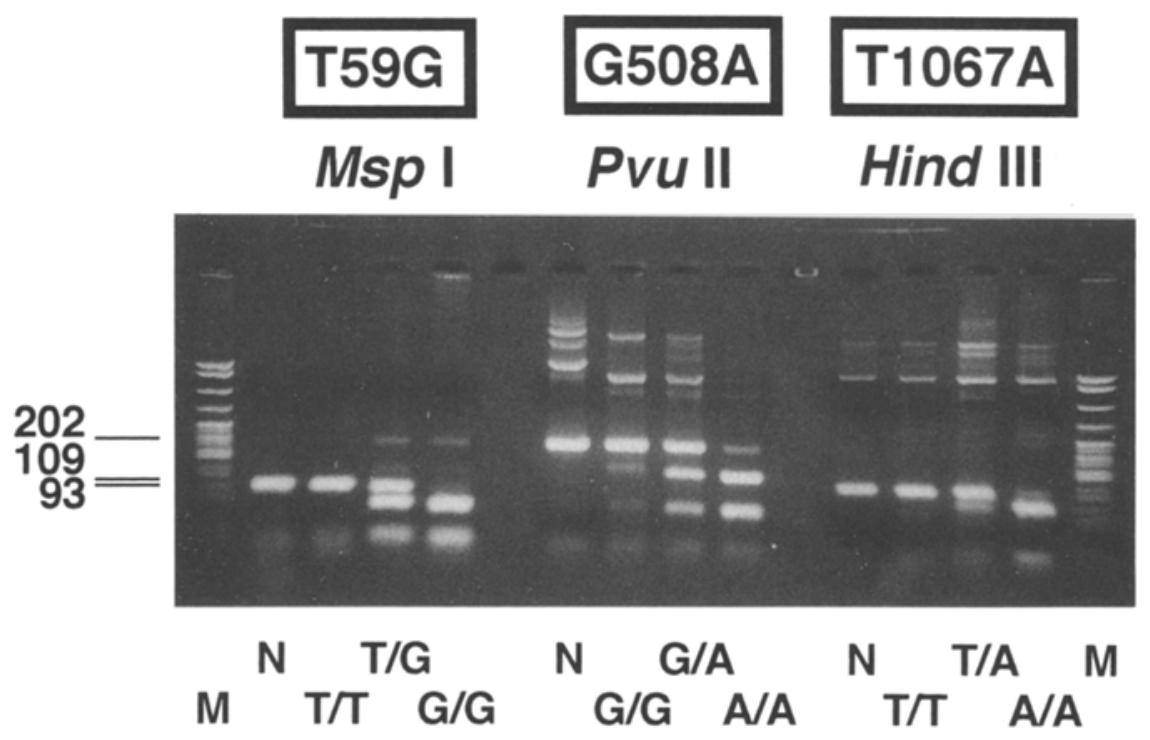

Fig. 3. PCR-RFLPs for detection of three single base substitutions found in Lewisnegative Fuc-TIII genes. The PCR-amplified DNAs of each genotype were tested with restriction enzyme and analyzed by a mixture of $1.5 \%$ Synergel and $0.7 \%$ agarose electrophoresis. The sizes were determined according to pBR322 DNA-MspI digest (M) run in parallel. N, no digestion. 
was then cleaved into two fragments, 85 and 24 bp by HindIII (Fig. 2, lower panel). The standard PCR-RFLPs to show individual genotypes were prepared using genomic DNAs obtained from peripheral blood leukocytes (Fig. 3). After Lewis genotyping of more than 100 samples, two individuals having homozygous T1067A missense mutation were found, for the first time, and their genotypes were assigned to le2/le2 (described below).

Twelve saliva samples comprising of $4 \mathrm{Le}(\mathrm{a}-\mathrm{b}+), 4 \mathrm{Le}(\mathrm{a}+\mathrm{b}-)$ and $4 \mathrm{Le}(\mathrm{a}-$ $\mathrm{b}-$ ) individuals were examined serologically with anti-Le ${ }^{\mathrm{a}}$ and anti-Le $\mathrm{b}^{\mathrm{b}}$ antibodies. The activity of $\alpha 1 \rightarrow 4$ fucosyltransferase (Le enzyme) was also examined with saliva samples at the same time (Table 2). The genomic DNAs of these 12 individuals were prepared from their hairs and PCR-RFLPs to detect three point mutations in the Le genes were carried out as described above (Fig. 4) and their Lewis genotypes were determined as summarized in the right column of Table 2. The Lewis-positive individuals whose saliva had Le enzyme activity and $\mathrm{Le}^{\mathrm{a}}$ and/ or $\mathrm{Le}^{\mathrm{b}}$ antigen were found to possess at least one $L e$ allele, and their genotypes were $L e / L e, L e / l e 1$ or Le/le 2 . On the other hand, the Lewis-negative individuals whose saliva didn't contain Lewis antigen nor Le enzyme activity were found to possess le genes homozygously and their genotypes were le $1 / l e 1, l e 1 / l e 2$ or $l e 2 / l e 2$ (Table 2). It was therefore demonstrated that the presence of Lewis antigen and Le enzyme activity was completely consistent with that of the Le gene. Furthermore, the first mutation in the $L e$ gene (T59 to G) was observed unexceptionally in le genes and then seemed to become a genetic marker to distinguish between Lewispositive and Lewis-negative individuals. No individual has been observed who

Table 2. Salivary $\alpha 1 \rightarrow 4$ fucosyltransferase activity and nucleic acid polymorphisms of $L e$ genes from individuals with blood group Lewis-positive and -negative phenotypes.

\begin{tabular}{|c|c|c|c|c|c|c|c|c|c|}
\hline \multirow{2}{*}{\multicolumn{2}{|c|}{ No. Donor }} & \multirow{2}{*}{$\begin{array}{l}\text { Blood } \\
\text { type }\end{array}$} & \multicolumn{2}{|c|}{$\mathrm{HAI}^{1}$ titer of saliva } & \multirow{2}{*}{$\begin{array}{c}\alpha 1 \rightarrow 4 \mathrm{FT}^{2} \\
\text { activity } \\
(\mathrm{pmol} / \mathrm{ml} / \mathrm{hr})\end{array}$} & \multicolumn{3}{|c|}{ PCR-RFLP, position } & \multirow{2}{*}{$\begin{array}{c}\text { Geno- } \\
\text { type }\end{array}$} \\
\hline & & & anti-Le ${ }^{\mathrm{a}}$ & anti-Le ${ }^{b}$ & & 59 & 508 & 1067 & \\
\hline \multicolumn{10}{|c|}{ Lewis-positive } \\
\hline 1. & M.S. L & $e(a-b+)$ & 16 & 128 & 52.33 & $\mathrm{~T}, \mathrm{~T}$ & $\mathrm{G}, \mathrm{G}$ & $\mathrm{T}, \mathrm{T}$ & $\mathrm{Le} / \mathrm{Le}$ \\
\hline 2. & M.M.L & $e(a-b+)$ & 4 & 128 & 44.35 & $\mathrm{~T}, \mathrm{G}$ & $\mathrm{G}, \mathrm{G}$ & $\mathrm{T}, \mathrm{A}$ & $L e / l e 2$ \\
\hline 3. & A.N. L & $(a-b+)$ & 4 & 64 & 29.15 & $\mathrm{~T}, \mathrm{~T}$ & $G, G$ & $\mathrm{~T}, \mathrm{~T}$ & Le/Le \\
\hline & H.O. L & $e(a-b+)$ & 32 & 512 & 8.98 & $\mathrm{~T}, \mathrm{~T}$ & $\mathrm{G}, \mathrm{G}$ & $\mathrm{T}, \mathrm{T}$ & Le/Le \\
\hline 5. & Y.N. L & $e(a+b-)$ & 128 & 8 & 12.80 & $\mathrm{~T}, \mathrm{G}$ & $\mathrm{G}, \mathrm{A}$ & $\mathrm{T}, \mathrm{T}$ & Le/lel \\
\hline 6. & A.M. L & $e(a+b-)$ & 128 & 4 & 92.69 & $\mathrm{~T}, \mathrm{~T}$ & $\mathrm{G}, \mathrm{G}$ & $\mathrm{T}, \mathrm{T}$ & Le/Le \\
\hline 7. & K.K. L & $e(a+b-)$ & 512 & 4 & 29.21 & $\mathrm{~T}, \mathrm{G}$ & $\mathrm{G}, \mathrm{A}$ & $\mathrm{T}, \mathrm{T}$ & Le/lel \\
\hline & H.M. L & $e(a+b-)$ & 128 & 8 & 16.05 & $\mathrm{~T}, \mathrm{G}$ & $\mathrm{G}, \mathrm{G}$ & $\mathrm{T}, \mathrm{A}$ & Le/le2 \\
\hline \multicolumn{10}{|c|}{ Lewis-negative } \\
\hline 9. & N.F. L & $e(a-b-)$ & 2 & 2 & 0 & $\mathrm{G}, \mathrm{G}$ & $\mathrm{A}, \mathrm{A}$ & $\mathrm{T}, \mathrm{T}$ & lel/lel \\
\hline 10. & K.N. L & $e(a-b-)$ & $<2$ & $<2$ & 0 & $\mathrm{G}, \mathrm{G}$ & $\mathrm{A}, \mathrm{A}$ & $\mathrm{T}, \mathrm{T}$ & lel/lel \\
\hline 11. & A.T. L & $e(a-b-)$ & $<2$ & 4 & 0 & $\mathrm{G}, \mathrm{G}$ & $\mathrm{G}, \mathrm{A}$ & $\mathrm{T}, \mathrm{A}$ & $l e 1 / l e 2$ \\
\hline 12. & T.T. L & $e(a-b-)$ & $<2$ & $<2$ & 0 & $\mathrm{G}, \mathrm{G}$ & $\mathrm{G}, \mathrm{G}$ & $\mathrm{A}, \mathrm{A}$ & le2/le2 \\
\hline
\end{tabular}

${ }^{1} \mathrm{HAI}$, hemagglutination inhibition; ${ }^{2} \mathrm{FT}$, fucosyltransferase. 
(a)

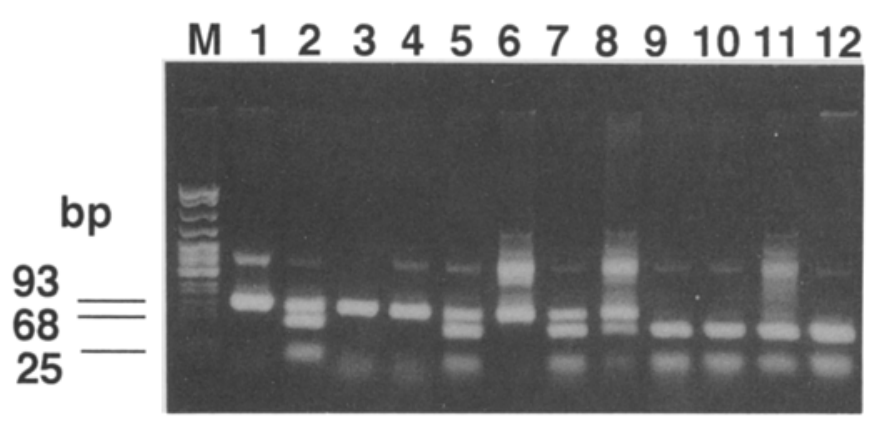

(b)

M 1223445677899101112

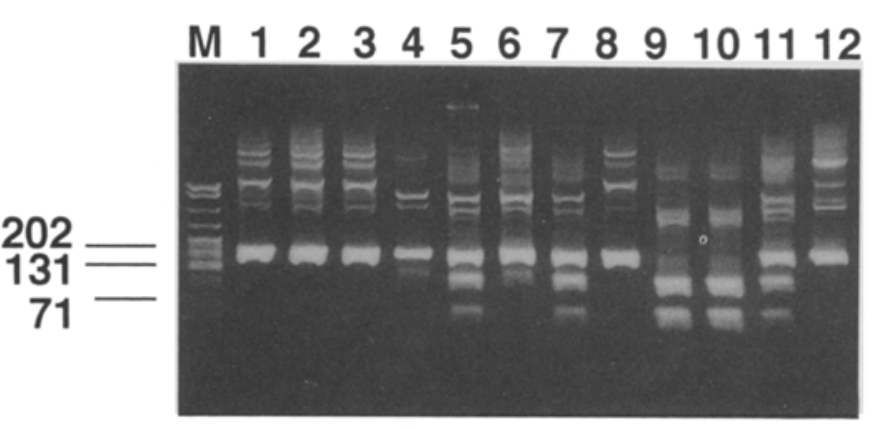

(c)

M 1223445667889101112

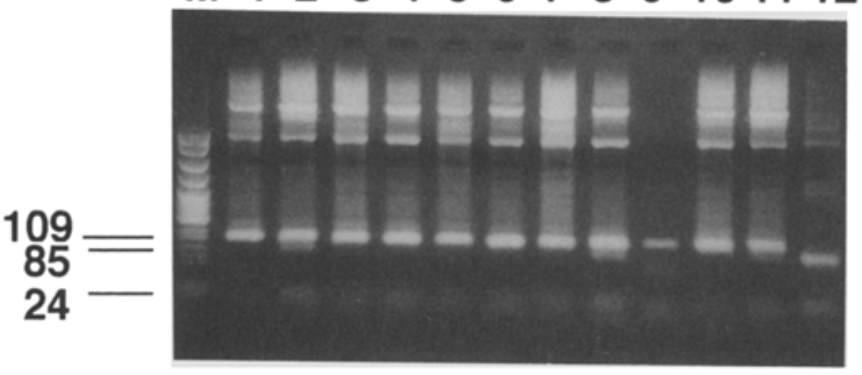

Fig. 4. PCR-RFLPs of Le, lel and le2 genes. PCR-RFLP for detection of the T59G mutation (a), the G508A mutation (b) and T1067A (c) after cleavage of MspI, $P v u I I$ and HindIII restriction enzymes, respectively. Gel electrophoresis was done as in Fig. 3. Lane numbers correspond to samples described in Table 2.

had only the T59G mutation without the G508A or the T1067A mutation after the Lewis genotyping of more than 200 specimens (data not shown).

Twelve of the 50 pregnant women showed Lewis-negative erythrocytes. Seven 
women among them showed the presence of $\mathrm{Le}^{\mathrm{a}}$ and/or $\mathrm{Le}^{\mathrm{b}}$ antigen in their plasma inconsistently (Table 3). The Lewis blood phenotypes have been reported to change from Lewis-positive to Lewis-negative during pregnancy (Hammer et al., 1981). It was then supposed that the seven women with Lewis-negative phenotypes whose plasma contained Lewis antigens were Lewis-positive, i.e., $\operatorname{Le}(a+b-)$ or $\operatorname{Le}(a-b+)$.

The Lewis genotyping of these 12 women to detect T59G mutation demonstrated that seven women who had $\mathrm{Le}^{\mathrm{a}}$ and/or Le ${ }^{\mathrm{b}}$ antigen in plasma possessed at least one $L e$ allele (Table 3). Two women (M.W. and M.Y.) whose saliva were available were found to have $\mathrm{Le}^{\mathrm{a}}$ antigen and $\mathrm{Le}^{\mathrm{b}}$ antigen, respectively and Le enzyme activity (data not shown). Recently, we determined the Lewis genotypes of Lewis-negative patients with cancers whose erythrocytes and saliva were found to show inconsistent Lewis phenotypes. The genotyping of their $L e$ genes demonstrated that some of them were non-genuine Lewis-negative and that patients who had Le enzyme activity were genuine Lewis-positive irrespective of their Lewis phenotypes (Yazawa et al., 1995). These results showed that the Lewis phenotypes from patients with cancer and pregnant women could not provide accurate information regarding the genuine Lewis blood types. However, it was clear that the single PCR-RFLP experiment to detect T59G mutation could be helpful for the determination of the genuine Lewis blood types and, in particular, for distinguishing Lewis-negative individuals from Lewis-positive ones correctly in such cases. More recently, molecular genetic analysis of $S e$ and se genes demonstrated the presence of $S e$ gene (FUT2 gene) encoding $\alpha 1 \rightarrow 2$ fucosyltransferase which relates to the synthesis of $\alpha 1 \rightarrow 2$ fucosyl residue of $H$ type 1 and $\mathrm{Le}^{\mathrm{b}}$ antigens in the secretor system (Rouquier et al., 1995; Kelly et al., 1995). It must be possible to determine Le $(a-b+)$ and Le $(a+b-)$ types from sequential genotypings of both the Le and

Table 3. Levels of plasma Lewis antigens, and their Lewis genotypes in pregnant women with Lewis-negative erythrocytes.

\begin{tabular}{|c|c|c|c|c|c|}
\hline \multirow{2}{*}{ Specimen } & \multirow{2}{*}{$\begin{array}{l}\text { Lewis } \\
\text { phenotype }\end{array}$} & \multicolumn{2}{|c|}{ Lewis antigen $(\mathrm{U} / \mathrm{ml})$} & \multirow{2}{*}{$\begin{array}{l}\text { Nucleotides of } \\
\text { Fuc-TIII position } 59\end{array}$} & \multirow{2}{*}{$\begin{array}{c}\text { Probable Lewis } \\
\text { genotype }\end{array}$} \\
\hline & & $\mathrm{Le}^{\mathrm{a}}$ & $\mathrm{Le}^{\mathrm{b}}$ & & \\
\hline M.W. & $\operatorname{Le}(a-b-)$ & 54.37 & 2.00 & $\mathrm{~T}, \mathrm{~T}$ & Le/Le \\
\hline M.Y. & $\operatorname{Le}(a-b-)$ & n.d. & 28.51 & $\mathrm{~T}, \mathrm{~T}$ & $\mathrm{Le} / \mathrm{Le}$ \\
\hline E.M. & $\operatorname{Le}(a-b-)$ & 48.01 & 91.70 & $\mathrm{~T}, \mathrm{G}$ & Le/le \\
\hline O.M. & $\operatorname{Le}(a-b-)$ & 37.81 & 5.22 & $\mathrm{~T}, \mathrm{G}$ & Le/le \\
\hline Y.Y. & $\operatorname{Le}(a-b-)$ & 254.81 & 8.08 & $\mathrm{~T}, \mathrm{~T}$ & $\mathrm{Le} / \mathrm{Le}$ \\
\hline I.M. & $\operatorname{Le}(a-b-)$ & 88.66 & 25.53 & $\mathrm{~T}, \mathrm{~T}$ & $\mathrm{Le} / \mathrm{Le}$ \\
\hline K.M. & $\operatorname{Le}(a-b-)$ & 39.24 & 1.59 & $\mathrm{~T}, \mathrm{G}$ & Le/le \\
\hline M.S. & $\operatorname{Le}(a-b-)$ & 3.41 & 2.01 & $\mathrm{G}, \mathrm{G}$ & le/le \\
\hline S.T. & $\operatorname{Le}(a-b-)$ & 3.83 & 3.88 & $\mathrm{G}, \mathrm{G}$ & le/le \\
\hline W.N. & $\operatorname{Le}(a-b-)$ & 3.12 & 5.82 & $\mathrm{G}, \mathrm{G}$ & le/le \\
\hline F.U. & $\operatorname{Le}(a-b-)$ & 1.42 & 6.14 & G,G & le/le \\
\hline Y.K. & $\operatorname{Le}(a-b-)$ & 3.41 & 2.01 & $\mathrm{G}, \mathrm{G}$ & le/le \\
\hline
\end{tabular}


Se genes which encodes the Lewis-dependent $\alpha 1 \rightarrow 4$ fucosyltransferase demonstrated by us and the secretor-dependent $\alpha 1 \rightarrow 2$ fucosyltransferase, respectively. The genotyping of both $L e$ and $S e$ genes, therefore seems to be indispensable to determine genuine $\operatorname{Le}(a-b-), \operatorname{Le}(a+b-)$ and $\operatorname{Le}(a-b+)$ types.

To evaluate the usefulness of the present Lewis genotyping for the paternity test, three cases under examination were picked up and Lewis genotyping of individuals was carried out using their blood stains (Fig. 5). In case 1, a daughter (A.S.) whose Lewis phenotype was $\mathrm{Le}(\mathrm{a}+\mathrm{b}-)$ possessed $l e l$ and Le genes. However, neither the putative father (N.K.) nor the mother (M.S.) possessed le1 gene and they were determined to be homozygote of Le genes. Although the Lewis phenotypes of the individuals in this case did not contribute to the test, it was clear that the putative father could be excluded from the candidate of her father from their Lewis genotypings. In cases 2 and 3, each daughter possessed le1 (N.G.) and le2 (N.K.) genes, respectively, which probably came from the putative fathers but not from their mothers whose Lewis genotypes were determined to be homozygote of $L e$ genes. In these cases, the putative fathers could not be excluded from the candidate. These results demonstrated that $l e 1, l e 2$ as well as Le genes determined by Lewis genotyping could be useful for the paternity tests and in some cases the Lewis genotyping could provide a conclusive result (as in case 1) which is hard to be obtained from the Lewis phenotyping.

While the conventional determination of Lewis blood types has been carried out mainly by serological examinations using anti-Le ${ }^{\mathrm{a}}$ and anti-Le ${ }^{\mathrm{b}}$ antibodies, there are problems for Lewis phenotyping with antibodies, in particular, in case when fresh and adequate samples are not available, and it is impossible to determine genuine Lewis blood types of the aforementioned individuals by the conventional analyses.
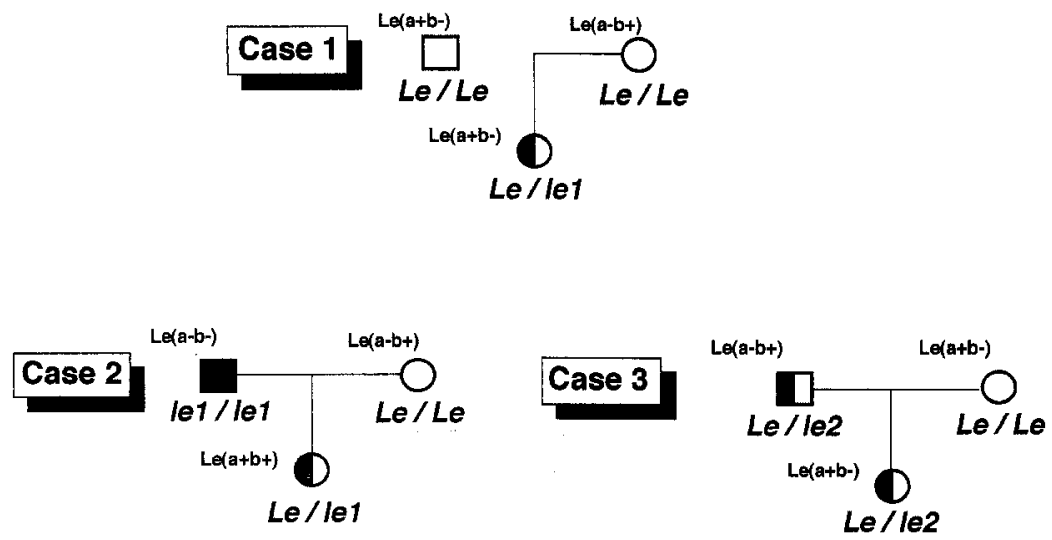

Fig. 5. Lewis genotyping of three cases of paternity tests. A slash separates two alleles. Filled, half-filled and open symbols indicate $l e / l e, L e / l e$ and $L e / L e$, respectively. 
In conclusion, we demonstrated not only the availability of the newly developed PCR-RFLP methods for Lewis genotypings but also the usefulness of the genotyping of $L e$ genes whose genuine Lewis blood group types were hard to be determined with the conventional methods.

Acknowledgments We thank Prof. H. Narimatsu, Division of Cell Biology, Institute of Life Science, Soka University, Tokyo, Japan, for valuable discussions with him. This study was supported in part by a Grant-in-Aid for Scientific Research (No. 01010001) from the Ministry of Education, Science and Culture of Japan and by a grant from Otsuka Pharmaceutical Company, Japan.

\section{REFERENCES}

American Association of Blood Banks (1981): Technical manual of the American Association of Blood Banks. 8th ed. Washington, DC, p 392

Ernst C, Atkinson B, Wysocka M, Blaszczyk M, Herlyn M, Sears H, Steplewsky Z, Koprowsky $H$ (1984): Monoclonal antibody localization of Lewis antigens in fixed tissue. Lab Invest 50: $394-400$

Good AH, Yau O, Lamontagne LR, Oriol R (1992): Serological and chemical specificities of twelve monoclonal anti-Le $\mathrm{e}^{\mathrm{a}}$ and anti-Le $\mathrm{e}^{\mathrm{b}}$ antibodies. Vox Sang 62: 180-189

Hammer L, Mansson S, Rohr T, Chester MA, Ginsburg V, Lundblad A, Zopf D (1981): Lewis-phenotype of erythrocytes and $\mathrm{Le}^{\mathrm{b}}$ active glycolipid in serum of pregnant women. Vox Sang 40: 27-33

Hirano K, Kawa S, Oguchi H, Kobayashi T, Yonekura H, Ogata H, Homma T (1987): Loss of Lewis antigen expression on erythrocytes in some cancer patients with high serum CA19-9 levels. J Natl Cancer Inst 79: 1261-1268

Kelly RJ, Rouquier S, Giorfi D, Lennon GG, Lowe JB (1995): Sequence and expression of a candidate for the human secretor blood group $\alpha(1,2)$ fucosyltransferase gene (FUT2). J Biol Chem 270: $4640-4649$

Kukowska-Latallo JF, Larsen RD, Nair RP, Lowe JB (1990): A cloned human cDNA determines expression of a mouse stage-specific embryonic antigen and the Lewis blood group $\alpha(1,3 /$ 1,4)fucosyltransferase. Genes Dev 4: 1288-1303

Limas C (1986): Detection of urothelial Lewis antigens with monoclonal antibodies. Am J Pathol 125: $515-523$

Lutz P, Dzik WH (1992): Molecular biology of red cell blood group genes. Transfusion 32: 467483

Makni S, Dalix AM, Caillard T, Compagnon B, Pendu JL, Ayed K, Oriol R (1987): Discordance between red cell and saliva Lewis phenotypes in patients with hydatid cysts. Exp Clin Immunogenet 4: 136-143

Nishihara S, Yazawa S, Iwasaki H, Nakazato N, Kudo T, Ando T, Narimatsu H (1993): $\alpha(1,3$ / 1,4)Fucosyltransferase (FucT-III) gene is inactivated by a single amino acid substitution in Lewis histo-blood type negative individuals. Biochem Biophys Res Commun 196: 624-631

Nishihara S, Narimatsu H, Iwasaki H, Yazawa S, Akamatsu S, Ando T, Seno T, Narimatsu I (1994): Molecular genetic analysis of the human Lewis histo-blood group system. J Biol Chem 269: 29271-29278

Oriol R, Sammelsson BE, Messeter L (1990): ABO antibodies-serological behavior and immuno-chemical characterization. J Immunogenet 17: 279-299

Ørntoft TF, Holmes H, Johnson J, Hakomori S, Clausen H (1991): Differential tissue expression

Vol. 41, No. 1, 1996 
of the Lewis blood antigens: enzymatic, immunohistologic, and immunochemical evidence for Lewis $\mathrm{a}$ and $\mathrm{b}$ antigen expression in $\operatorname{Le}(\mathrm{a}-\mathrm{b}-)$ individuals. Blood 77: 1389-1396

Rouquier S, Lowe JB, Kelly J, Fertitta AL, Lennon GG, Giorgi D (1995): Molecular cloning of a human genomic region containing the $\mathrm{H}$ blood group $\alpha(1,2)$ fucosyltransferase gene and two $H$ locus-related DNA restriction fragments. J Biol Chem 270: 4632-4639

Sabrock J, Fritsch EF, Maniatis T (1992): Molecular cloning: A laboratory manual. 2nd ed., Cold Spring Harbor Laboratory Press, New York, 2.80

Schachter H (1994): Molecular cloning of glycosyltransferase genes. In: Fukuda M, Hindusgaul O (eds). Molecular glycobiology, IRL Press, New York, pp 88-162

Stigendal L, Olsson R, Rydberg L, Samuelsson BE (1984): Blood group Lewis phenotype on erythrocytes and in saliva in alcoholic pancreatitis and chronic liver disease. J Clin Pathol 37: $778-786$

Watkins WM (1980): Biochemistry and genetics of the ABO, Lewis and P blood group system. Ady Hum Genet 10: 1-136

Yazawa S, Asao T, Izawa H, Miyamoto Y, Matta KL (1988): The presence of CA19-9 in serum and saliva from Lewis blood-group negative cancer patients. Jpn J Cancer Res 79: 538-543

Yazawa S, Madiyalakan R, Jain RJ, Shimoda N, Matta KL (1990a): Use of benzyl 2-acetamido-2deoxy-3-O-(2-O-methyl- $\beta$-D-galactosyl)- $\beta$-D-glucopyranoside $\quad\left[2^{\prime}-O\right.$-methyllacto- $N$-biose $\mathrm{I} \beta \mathrm{Bn}]$ as a specific acceptor for GDP-fucose: $N$-acetylglucosaminide $\alpha(1 \rightarrow 4)$-L-fucosyltransferase. Anal Biochem 187: 374-378

Yazawa S, Kochibe N, Asao I (1990b): A simple procedure for isolation of tumor-associated antigens by affinity chromatography using fucose-specific Aleuria aurantia lectin. Immunol Invest 19: 319-327

Yazawa S, Takeya A, Hosomi O, Nakajima T, Shimoda N, Ohi H, Tachikawa T, Piscorz CF, Jain RK, Matta KL (1992): Use of synthetic H-disaccharides as acceptors for detecting activities of UDP-GalNAc:Fuc $\alpha 1 \rightarrow 2 \mathrm{Gal} \beta-\mathrm{R} \alpha \mathrm{l} \rightarrow 3-N$-acetylgalactosaminyltransferase in plasma samples from blood group A subgroups. Clin Chem 38: 2392-2395

Yazawa S, Akamatsu S, Tachikawa T, Naito H, Nakamura J, Asao T, Nagamachi Y, Nakajima T, Shin S, Chia D (1993): Development and characterization of a novel anti-fucosylated antigen monoclonal antibody YB-2 and its usefulness in the immunohistochemical diagnosis of colorectal cancer. Jpn J Cancer Res 84: 641-648

Yazawa S, Nishihara S, Iwasaki H, Asao T, Nagamachi Y, Matta KL, Narimatsu H (1995): Genetic and enzymatic evidence for Lewis enzyme expression in Lewis-negative cancer patients. Cancer Res 55: 1473-1478 